\title{
Novel design principle validated: Glucopyranosylidene-spiro-oxathiazole as new nanomolar inhibitor of glycogen phosphorylase, potential antidiabetic agent
}

\author{
László Somsák ${ }^{\mathrm{a}, *}$, Veronika Nagy ${ }^{\mathrm{a}, \mathrm{b}}$, Sébastien Vidal ${ }^{\mathrm{b}, c, \mathrm{~d}}$, Katalin Czifrák ${ }^{\mathrm{a}}$, Eszter Berzsényi ${ }^{\mathrm{a}}$, \\ Jean-Pierre Praly b,c,d,* \\ a Department of Organic Chemistry, University of Debrecen, PO Box 20, H-4010 Debrecen, Hungary \\ ${ }^{\mathrm{b}}$ CNRS, UMR5246, Institut de Chimie et Biochimie Moléculaires et Supramoléculaires, Laboratoire de Chimie Organique 2-Glycochimie, \\ 43 Boulevard du 11 Novembre 1918, F-69622 Villeurbanne, France \\ ' Université de Lyon, F-69622 Lyon, France \\ dUniversité Lyon 1, 43 Boulevard du 11 Novembre 1918, F-69622 Villeurbanne, France
}

\section{A R T I C L E I N F O}

\section{Article history:}

Received 23 July 2008

Revised 14 August 2008

Accepted 15 August 2008

20 Available online $\mathrm{xxxx}$

\section{A B S T R A C T}

2-Naphthyl-substituted glucopyranosylidene-spiro-oxathiazole prepared following a novel design principle was found to be the best known glucose analogue inhibitor of rabbit muscle glycogen phosphorylase b $\left(K_{\mathrm{i}} 160 \mathrm{nM}\right)$.

(c) 2008 Published by Elsevier Ltd.

Keywords:

Glycogen phosphorylase

Inhibitor

Glucose analogue

Oxathiazole

Spirocyclization

Spiro-bicyclic sugar

Glycogen phosphorylase (GP) is a peculiar glycoenzyme involved in the breakdown of the storage polysaccharide glycogen. ${ }^{1}$ The liver isoform of GP is the rate limiting enzyme of glycogen metabolism and is, therefore, directly responsible for regulating blood sugar levels. Evidence are accumulating that in the non-insulin dependent (type 2 ) form of diabetes mellitus, ${ }^{2}$ comprising more than $90 \%$ of all diagnosed cases, ${ }^{3,4}$ elevated hepatic glucose output is the most important cause of hyperglycemia. ${ }^{5-8}$ Thus, GP is a validated target for the treatment of type 2 diabetes and its inhibition appears of great interest in both academia and industry. ${ }^{9-11}$ GP has six known binding sites for which several inhibitors have been identified. ${ }^{12,13}$ Among these, glucose-based compounds represent a large family with the capability of binding at the catalytic site of the enzyme in most cases with very high selectivity. ${ }^{14-16}$

$N$-Acetyl- $\beta$-D-glucopyranosylamine ${ }^{17}(\mathbf{1}$, Chart 1$)$ was among the first efficient glucose analogue inhibitors of rabbit muscle $\mathrm{GPb}$ (RMGPb). Analogous compounds with aromatic substituents as $\mathbf{2}^{17,18}$ and $\mathbf{3}^{19}$ showed weaker binding properties, and $\mathbf{4}^{19}$ was only slightly better than $\mathbf{1}$. As a corollary of early inhibitor design

\footnotetext{
* Corresponding authors. Tel.: +36 52512 900; fax: +36 52453836 .

E-mail address: somsak@tigris.unideb.hu (L. Somsák).
}

based on glucose derivatives, spiro-hydantoin $5^{18,20}$ reached the low micromolar range and its thiohydantoin analogue $6^{18}$ proved similarly efficient. Extensive protein crystallographic investigations of the corresponding GP-inhibitor complexes showed that a $\mathrm{H}$-bridge between the $\beta$-anomeric $\mathrm{NH}$ and His 377 main chain carbonyl of the enzyme exists for both $N$-acyl- $\beta$-D-glucopyranosylamines ${ }^{17,21} \mathbf{1 - 4}$ and spiro-hydantoins ${ }^{22-24} \mathbf{5}$ and $\mathbf{6}$ (see outline $\mathbf{A}$ in Chart 1). This feature was then considered as a main contribution to the strong binding of glucose analogues at the catalytic site of GP, and became almost a dogma for further inhibitor design. In the cases of the spiro-hydantoins, the rigid structure of the planar (thio)hydantoin rings, and that of the bicyclic ring system as a whole was also accounted for the tight binding. ${ }^{22,23}$

In recent years, we have introduced several new classes of glucose-based compounds as inhibitors of GP displaying inhibition constants in the low micromolar range, among others $N$-acyl- $N^{\prime}-$ $\beta$-D-glucopyranosyl ureas ${ }^{13,16,25-28} \mathbf{7 - 1 0}$ and $C$ - $(\beta$-D-glucopyranosyl) derivatives of aromatic heterocycles such âs 1,3,4-oxadiazole, benzothiazole and benzimidazole, ${ }^{29,30}$ as well as 1,2,4-oxadiazoles. $^{31,32}$ The latter heterocyclic derivatives (apart from the benzimidazole) cannot form $\mathrm{H}$-bridges similar to those discussed above because of the lack of suitable hydrogens. On the other hand 


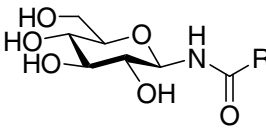

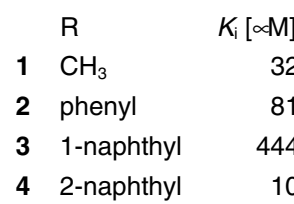

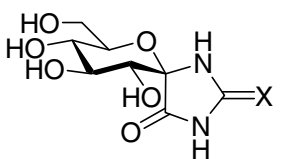

$\begin{array}{rrrr} & \mathrm{X} & K_{\mathrm{i}}[\propto \mathrm{M}] \\ \mathbf{5} & \mathrm{O} & 3.1 \\ & & 4.3 \\ 6 & \mathrm{~S} & 5.1\end{array}$

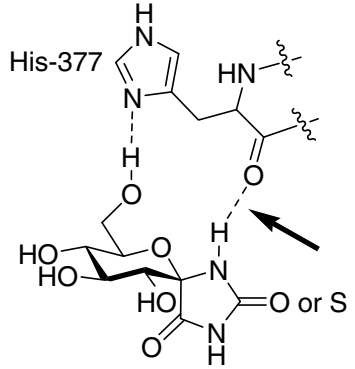

A

$\mathrm{H}$-bridges between His-377 and $\mathrm{N}$-acyl- -D-glucopyranosylamine as well as spiro-hydantoin type inhibitors at the catalytic site of GP

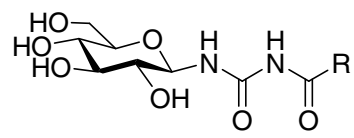

No H-bridge of the above type!
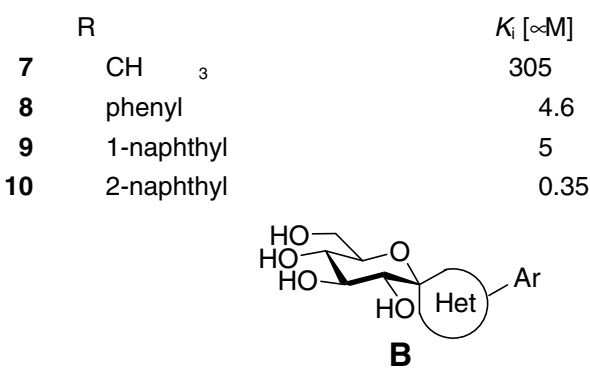

Synthetic goal: rigid bicyclic structure having a properly oriented/substituted aromatic group with or without a $\mathrm{H}$-bond donor capacity towards His 377

Chart 1. Some glucose-based GP inhibitors (1-10) with their inhibition constants $\left(K_{\mathrm{i}}\right.$ against RMGPb); characteristic binding mode of some inhibitors $(\mathrm{A})$; and general structure of the spiro-bicyclic inhibitors (B).

and rather surprisingly, the absence of this particular $\mathrm{H}$-bond to His 377 was demonstrated by crystallography for $\mathbf{8}^{-10^{25,27,28}}$ (note that 7 binds to the enzyme in a different conformation ${ }^{25}$ in which the $\beta$-anomeric $\mathrm{NH}$ is involved in an intramolecular $\mathrm{H}$-bridge with the acetyl CO). Comparison of the efficiency of inhibition for the pairs 2 and 8,3 and 9 and 4 and 10 shows a significant increase in affinity to the enzyme in favour of the acyl ureas by a factor of $\sim 18, \approx 89$ and $\sim 29$, respectively. Thus, even in the absence of that most important $\mathrm{H}$-bond, very strong binding is possible which must be ascribed to the interactions of the inhibitor with the socalled $\beta$-channel ${ }^{9,16}$ (an empty space in the direction of the $\beta$-anomeric substituent of bound - $^{-g l u c o s e}$ surrounded by amino acid side chains of mixed character) of the enzyme next to the catalytic site. This is further corroborated by the comparison of inhibition by 9 and 10 ( $\sim 14$-fold increase) showing that the orientation of the aromatic part of the molecule is extremely important in order to properly fit into the $\beta$-channel as it was also demonstrated by Xray crystallography. ${ }^{28}$

Based on these findings, we envisaged that a novel design principle for efficient glucose-based inhibitors of GP can be set up which unifies the properties of the best inhibitors (see generalized formula B in Chart 1): (i) such molecules should have a rigid spirobicyclic scaffold in which a (preferably five-membered hetero)cycle is attached to the anomeric carbon of $\beta$-D-glucopyranose, (ii) this cycle, although it may, should not necessarily be a H-bond donor towards His 377 and (iii) a suitably oriented, large aromatic appendage must be present on this cycle to fit into the $\beta$-channel.

In this letter we present some glucopyranosylidene-spiro-oxathiazoles as the first compounds which meet the above design principle and one of them is the most efficient glucose analogue inhibitor of GP known to date.

The synthesis of glycopyranosylidene-spiro-oxathiazoles in a minimum number of steps was previously reported. ${ }^{33,34}$ Besides the known $14 a^{33}$ we synthesized substituted phenyl derivatives 14b and 14c as well as 2-naphthyl derivative 14d (Scheme 1). Reaction of nitrile oxides, obtained in situ by base treatment of hydroximoyl chlorides, ${ }^{35}$ with the readily available 2,3,4,6-tetra$O$-acetyl-1-thio- $\beta$-D-glucopyra-nose ${ }^{36}$ (11) afforded the corresponding thiohydroximates $12 \mathrm{a}-\mathbf{d}^{37}$ in good yields. The spirocyclization under photochemical conditions afforded the acetylated glucopyranosylidene-spiro-oxathiazoles $13 a-d^{38}$ and subsequent deacetylation under basic transesterification conditions provided the $O$-unprotected target molecules $14 a-d .^{39}$ The spirocyclization process was stereoselective with the oxygen atom adopting predominantly the axial position as previously demon-

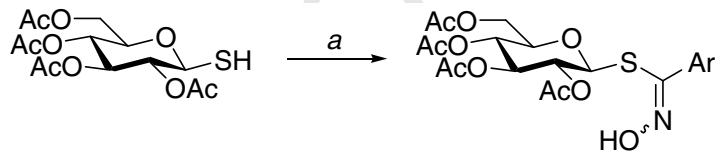
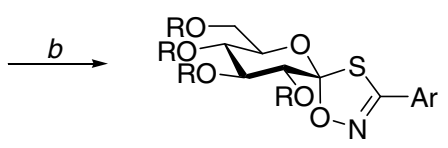

11<smiles>COc1ccc(C)cc1</smiles>

12

$90^{41}$

b

d

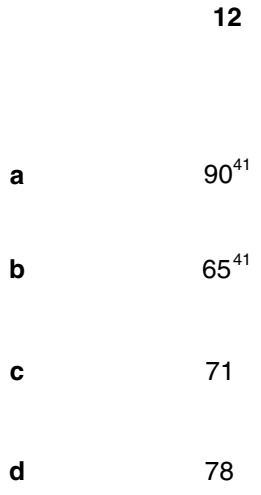<smiles>C1CCCC1</smiles>

$$
\begin{gathered}
13 \\
(R=A c)
\end{gathered}
$$

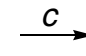

Yield (\%)

$46^{33}$

$30^{33}$

69

36

$(\mathrm{R}=\mathrm{H})$

Yield (\%)

$K_{\mathrm{i}}^{\star}[\mu \mathrm{M}]$

$90^{33}$

$26 \pm 2.1$

79

$28 \pm 2.8$

79

$8 \pm 0.9$

94

$0.16 \pm 0.04$

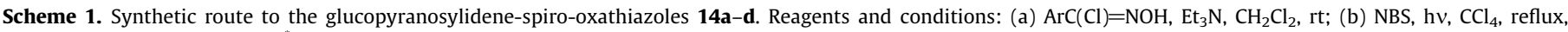
$45 \mathrm{~min}$; (c) NaOMe, MeOH, rt. "Inhibition constants $\left(K_{\mathrm{i}}\right)$ measured for 14 against RMGPb. 
strated and the main product was isolated by column chromatography.

The GP inhibitor candidates were evaluated for their inhibition against RMGPb enzyme as previously described ${ }^{40}$ and the obtained inhibitor constants $\left(K_{\mathrm{i}}\right)$ are shown in Scheme 1. The phenyl derivative 14a proved $\sim 5$ times weaker inhibitor than the corresponding acyl urea 8. Substitution of the phenyl ring in the 4-position by a fluorine (14b) brought about no change probably due to the similar size of the $\mathrm{H}$ and $\mathrm{F}$ atoms. Introduction of a methoxy group into the same position (14c) made a $\sim 3$ times better inhibitor than 14a suggesting that a bulky substituent on the phenyl ring can be beneficial. Finally, the 2-naphthyl derivative (14d) inhibited the enzyme $\sim 2$ times stronger than $\mathbf{1 0}$. These preliminary results demonstrate that the combination of a rigid spiro-bicyclic structure with the introduction of a large hydrophobic aromatic moiety in a proper orientation for an optimal interaction with the enzyme significantly improves the biological activity of the molecules.

The 2-naphthyl substituted derivative 14d is the most potent glucose-based inhibitor of GP to date with an inhibition in the nanomolar range. Based on these preliminary results, we are now synthesizing a more populated family of glucopyranosylidenespiro-oxathiazoles for their biological evaluation as GP inhibitors. These molecules are expected to bind at the catalytic site of GP and further enzymatic and crystallographic investigations will be reported elsewhere.

\section{Uncited reference}

Q1 Ref. 41.

\section{Acknowledgments}

Financial support for this work was provided by the Hungarian Scientific Research Fund (OTKA 46081, 61336). Collaboration between Lyon and Debrecen was facilitated by PICS Program NO. 4576 financed by CNRS (France) and the Hungarian Academy of Sciences (Hungary). V.N. thanks the French Embassy in Budapest for initiating and supporting a co-tutored PhD Thesis in Debrecen and Lyon. For the preliminary enzyme kinetic measurements the authors are indebted to T. Docsa and P. Gergely (University of Debrecen, Hungary).

\section{References and notes}

1. Johnson, L. N. FASEB J. $1992,6,2274$

2. Hengesh, E. J. In Principles of Medicinal Chemistry; Foye, W. O., Lemke, T. L., Williams, D. A., Eds.; Springer: Baltimore, 1995; pp 581-600.

3. Moller, D. E. Nature 2001, 414, 821

4. Zimmet, P.; Alberti, K. G. M. M.; Shaw, J. Nature 2001, 414, 782.

5. Staehr, P.; Hother-Nielsen, O.; Beck-Nielsen, H. Diabetes Obes. Metab. 2002, 4, 215.

6. Roden, M.; Bernroider, E. Best Pract. Res. Clin. Endocrin. Metab. 2003, 17, 365.

7. Kurukulasuriya, R.; Link, J. T.; Madar, D. J.; Pei, Z.; Rohde, J. J.; Richards, S. J.; Souers, A. J.; Szczepankiewicz, B. G. Curr. Med. Chem. 2003, 10, 99.

8. Ross, S. A.; Gulve, E. A.; Wang, M. H. Chem. Rev. 2004, 104, 1255.

9. Oikonomakos, N. G. Curr. Protein Pept. Sci. 2002, 3, 561.

10. Baker, D. J.; Greenhaff, P. L.; Timmons, J. A. Expert Opin. Ther. Patents 2006, 16, 459.

11. Agius, L. Best Pract. Res. Clin. Endocrin. Metab. 2007, 21, 587.

12. Henke, B. R.; Sparks, S. M. Mini-Rev. Med. Chem. 2006, 6, 845.

13. Oikonomakos, N. G.; Somsák, L. Curr. Opin. Invest. Drugs 2008, 9, 379.

14. Somsák, L.; Nagy, V.; Hadady, Z.; Docsa, T.; Gergely, P. Curr. Pharm. Des. 2003, 9, 1177.

15. Somsák, L.; Nagy, V.; Hadady, Z.; Felföldi, N.; Docsa, T.; Gergely, P. In Frontiers in Medicinal Chemistry; Reitz, A. B.; Kordik, C. P.; Choudhary, M. I.; Rahman, A. u., Eds.; Bentham, 2005; pp. 253-272.

16. Somsák, L.; Czifrák, K.; Tóth, M.; Bokor, É.; Chrysina, E. D.; Alexacou, K. M.; Hayes, J. M.; Tiraidis, C.; Lazoura, E.; Leonidas, D. D.; Zographos, S. E.; Oikonomakos, N. G. Curr. Med. Chem., in press.

17. Watson, K. A.; Mitchell, E. P.; Johnson, L. N.; Cruciani, G.; Son, J. C.; Bichard, C. J. F.; Fleet, G. W. J.; Oikonomakos, N. G.; Kontou, M.; Zographos, S. E. Acta Cryst. 1995, D51, 458.
18. Somsák, L.; Kovács, L.; Tóth, M.; Ősz, E.; Szilágyi, L.; Györgydeák, Z.; Dinya, Z.; Docsa, T.; Tóth, B.; Gergely, P. J. Med. Chem. 2001, 44, 2843.

19. Györgydeák, Z.; Hadady, Z.; Felföldi, N.; Krakomperger, A.; Nagy, V.; Tóth, M.; Brunyánszky, A.; Docsa, T.; Gergely, P.; Somsák, L. Bioorg. Med. Chem. 2004, 12, 4861.

20. Bichard, C. J. F.; Mitchell, E. P.; Wormald, M. R.; Watson, K. A.; Johnson, L. N.; Zographos, S. E.; Koutra, D. D.; Oikonomakos, N. G.; Fleet, G. W. J. Tetrahedron Lett. 1995, 36, 2145.

21. Anagnostou, E.; Kosmopoulou, M. N.; Chrysina, E. D.; Leonidas, D. D.; Hadjiloi, T.; Tiraidis, C.; Zographos, S. E.; Györgydeák, Z.; Somsák, L.; Docsa, T.; Gergely, P.; Kolisis, F. N.; Oikonomakos, N. G. Bioorg. Med. Chem. 2006, 14, 181.

22. Gregoriou, M.; Noble, M. E. M.; Watson, K. A.; Garman, E. F.; Krülle, T. M.; Fuente, C.; Fleet, G. W. J.; Oikonomakos, N. G.; Johnson, L. N. Protein Sci. 1998, 7, 915.

23. Oikonomakos, N. G.; Skamnaki, V. T.; Ösz, E.; Szilágyi, L.; Somsák, L.; Docsa, T.; Tóth, B.; Gergely, P. Bioorg. Med. Chem. 2002, 10, 261.

24. Watson, K. A.; Chrysina, E. D.; Tsitsanou, K. E.; Zographos, S. E.; Archontis, G.; Fleet, G. W. J.; Oikonomakos, N. G. Proteins: Struct. Funct. Bioinf. 2005, 61, 966.

25. Oikonomakos, N. G.; Kosmopolou, M.; Zographos, S. E.; Leonidas, D. D.; Somsák L.; Nagy, V.; Praly, J.-P.; Docsa, T.; Tóth, B.; Gergely, P. Eur. J. Biochem. 2002, 269, 1684 .

26. Somsák, L.; Felföldi, N.; Kónya, B.; Hüse, C.; Telepó, K.; Bokor, É.; Czifrák, K. Carbohydr. Res. 2008, 343, 2083.

27. Nagy, V.; Felföldi, N.; Praly, J.-P.; Docsa, T.; Gergely, P.; Chrysina, E. D.; Tiraidis, C.; Alexacou, K. M.; Leonidas, D. D.; Zographos, S. E.; Oikonomakos, N. G.; Somsák, L., in preparation.

28. Chrysina, E. D.; Nagy, V.; Felföldi, N.; Telepó, K.; Praly, J.-P.; Docsa, T.; Gergely, P.; Alexacou, K. M.; Hayes, J. M.; Leonidas, D. D.; Zographos, S. E.; Oikonomakos, N. G.; Somsák, L., in preparation.

29. Hadady, Z.; Tóth, M.; Somsák, L. Arkivoc 2004, 140. Leonidas, D. D.; Hadady, Z.; Somsák, L.; Docsa, T.; Gergely, P.; Oikonomakos, N. G. Protein Sci. 2005, 14, 873.

31. Benltifa, M.; Vidal, S.; Gueyrard, D.; Goekjian, P. G.; Msaddek, M.; Praly, J.-P. Tetrahedron Lett. 2006, 47, 6143

32. Benltifa, M.; Vidal, S.; Fenet, B.; Msaddek, M.; Goekjian, P. G.; Praly, J.-P.; Brunyánszki, A.; Docsa, T.; Gergely, P. Eur. J. Org. Chem. 2006, 4242.

33. Praly, J.-P.; Faure, R.; Joseph, B.; Kiss, L.; Rollin, P. Tetrahedron 1994, 50, 6559.

34. Elek, R.; Kiss, L.; Praly, J. P.; Somsák, L. Carbohydr. Res. 2005, 340, 1397.

35. Liu, K. C.; Shelton, B. R.; Howe, R. K. J. Org. Chem. 1980, 45, 3916.

36. Černý, M.; Vrkoč, J.; Stanek, J. Coll. Czech. Chem. Commun. 1959, 24, 64

37. Typical procedure I: 2,3,4,6-Tetra-O-acetyl-1-thio- $\beta$-D-glucopyranose (11, $0.363 \mathrm{~g}, 1 \mathrm{mmol})$ dissolved in $\mathrm{CH}_{2} \mathrm{Cl}_{2}(5 \mathrm{~mL})$ and $\mathrm{Et}_{3} \mathrm{~N}(0.42 \mathrm{~mL}, 3 \mathrm{mmol})$ were added under an $\mathrm{Ar}$ atmosphere with continuous stirring to a solution of a hydroximoyl chloride $(1.2 \mathrm{mmol})$ in $\mathrm{Et}_{2} \mathrm{O}$ or $\mathrm{CH}_{2} \mathrm{Cl}_{2}(5 \mathrm{~mL})$. After immediate precipitation of $\mathrm{Et}_{3} \mathrm{~N} \cdot \mathrm{HCl}$, the mixture was stirred further at rt. When TLC indicated completion of the transformation $(\sim 1 \mathrm{~h}), 0.5 \mathrm{M} \mathrm{H}_{2} \mathrm{SO}_{4}(20 \mathrm{~mL})$ was added, and the organic phase was separated, washed by water $(2 \times 20 \mathrm{~mL})$, and dried $\left(\mathrm{MgSO}_{4}\right)$. After removal of the solvent under diminished pressure, the residue was purified by crystallization or column chromatography to afford the desired acetylated hydroximothioates 12a-d. Characterization for 12d: $R_{f}$ $=0.25(\mathrm{PE} /$ EtOAc, $2: 1) ;[\alpha]_{\mathrm{D}}{ }^{25}+4.5(\mathrm{c} 0.29, \mathrm{MeOH}) ; \mathrm{mp}=154-156{ }^{\circ} \mathrm{C} ;{ }^{1} \mathrm{H}$ NMR $\left(360 \mathrm{MHz}^{\mathrm{CDCl}} \mathrm{CD}_{3}\right) \delta 1.90,1.95,2.05,2.07\left(4 \mathrm{~s}, 12 \mathrm{H}, 4 \times \mathrm{CH}_{3}\right), 2.96$ (ddd, $1 \mathrm{H}, \mathrm{H}-5$ ), $3.92\left(\mathrm{dd}, 1 \mathrm{H}, J_{5,6^{\prime}}=2.6 \mathrm{~Hz}, \mathrm{H}-6^{\prime}\right), 4.05\left(\mathrm{dd}, 1 \mathrm{H}, J_{5,6}=3.9 \mathrm{~Hz}, J_{6,6}=11.9 \mathrm{~Hz}, \mathrm{H}-6\right)$, 4.55 (d, $1 \mathrm{H}, J_{1,2}=9.2 \mathrm{~Hz}, \mathrm{H}-1$ ), 5.09, 5.04, 4.97 (3t, 3H, $J=9.2 \mathrm{~Hz}, \mathrm{H}-2, \mathrm{H}-3, \mathrm{H}-4$ ), $7.50-8.10(\mathrm{~m}, 7 \mathrm{H}, \mathrm{H}-\mathrm{ar}), 10.07(\mathrm{~s}, 1 \mathrm{H}, \mathrm{OH}) ;{ }^{13} \mathrm{C}$ NMR $\left(90 \mathrm{MHz}, \mathrm{CDCl}_{3}\right) \delta 20.6$, 20.5, 20.4, $20.3\left(\mathrm{CH}_{3}\right), 61.4$ (C-6), 75.4, 73.6, 69.8, 67.6 (C-2, C-3, C-4, C-5), 88.3 (C-1) $125.6,126.8,127.3,127.7,127.9,128.3,129.8,132.6,133.5$ (aromatics) $151.9(\mathrm{C}=\mathrm{N}), 170.6,170.2,169.2(\mathrm{C}=\mathrm{O})$; Anal. Calcd for $\mathrm{C}_{25} \mathrm{H}_{27} \mathrm{NO}_{10} \mathrm{~S}(533.56)$ : C, 56.28; H, 5.10; N, 2.63; S, 6.01. Found: C, 56.41; H, 5.06; N, 2.44; S, 5.88.

38. Typical procedure II: A solution of hydroximothioate $12 \mathbf{a}-\mathbf{d}(1 \mathrm{mmol})$ and $N$ bromosuccinimide $(2 \mathrm{mmol})$ in $\mathrm{CCl}_{4}(20 \mathrm{~mL})$ was boiled and illuminated by a $60 \mathrm{~W}$ heat lamp for $45 \mathrm{~min}$. The reaction was diluted with EtOAc $(150 \mathrm{~mL})$ and the organic layer was washed with $5 \%$ aqueous $\mathrm{Na}_{2} \mathrm{SO}_{3}(2 \times 100 \mathrm{~mL})$ and water $(2 \times 100 \mathrm{~mL})$, dried $\left(\mathrm{Na}_{2} \mathrm{SO}_{4}\right)$, filtered and evaporated under reduced pressure. The residue was purified by flash column chromatography (PE then PE/EtOAc 65:35) to afford the desired acetylated spiro-oxathiazoles 13a-d. Characterization for 13d: $R_{\mathrm{f}}=0.59$ (PE/EtOAc, 3:2); $[\alpha]_{\mathrm{D}}{ }^{20}+44\left(c 1, \mathrm{CH}_{2} \mathrm{Cl}_{2}\right)$; ${ }^{1} \mathrm{H}$ NMR $\left(300 \mathrm{MHz}, \mathrm{CDCl}_{3}\right) \delta 2.04,2.06,2.09$ (3s, 12H, $\left.4 \times \mathrm{CH}_{3}\right), 4.09$ (dd, $1 \mathrm{H}$, $\left.J_{6,5}=2.1 \mathrm{~Hz}, J_{6,6^{\prime}}=12.7 \mathrm{~Hz}, \mathrm{H}-6\right), 4.35$ (dd, $1 \mathrm{H}, J_{6^{\prime}, 5}=3.7 \mathrm{~Hz}, J_{6^{\prime}, 6}=12.7 \mathrm{~Hz}, \mathrm{H}-6^{\prime}$ ), 4.45 (ddd, $\left.1 \mathrm{H}, J_{5,6}=2.1 \mathrm{~Hz}, J_{5,6}=3.7 \mathrm{~Hz}, J_{5,4}=10.3 \mathrm{~Hz}, \mathrm{H}-5\right), 5.28(\mathrm{~m}, 1 \mathrm{H}, \mathrm{H}-4)$, $5.66(\mathrm{~m}, 2 \mathrm{H}, \mathrm{H}-2 \mathrm{H}-3), 7.51-7.62(\mathrm{~m}, 2 \mathrm{H}, \mathrm{H}-\mathrm{ar}), 7.84-7.90$ (m, 4H, H-ar), 8.01 (s, $1 \mathrm{H}, \mathrm{H}-\mathrm{ar}) ;{ }^{13} \mathrm{C}$ NMR $\left(75 \mathrm{MHz}, \mathrm{CDCl}_{3}\right) \delta 20.4,20.6\left(\mathrm{CH}_{3}\right), 61.1(\mathrm{C}-6), 67.5(\mathrm{C}-4)$, 68.0 (C-2 or C-3), 70.7 (C-5), 71.1 (C-2 or C-3), 122.4 (C-1), 123.5, 124.4, 127.1, $127.8,128.0,128.6,128.8,129.4,132.7,134.6$ (aromatics), $156.5(\mathrm{C}=\mathrm{N}), 169.4$, 169.5, 169.7, $170.5(\mathrm{C}=0)$; MS (ESI) $m / z=531.7[\mathrm{M}+\mathrm{H}]^{+}, 554.0[\mathrm{M}+\mathrm{Na}]^{+}, 1062.6$ $[2 \mathrm{M}+\mathrm{H}]^{+}, 1084.7[2 \mathrm{M}+\mathrm{Na}]^{+}$; HRMS (ESI) $m / z=\mathrm{C}_{25} \mathrm{H}_{25} \mathrm{NNaO}_{10} \mathrm{~S}[\mathrm{M}+\mathrm{Na}]^{+}$Calcd 554.1097. Found 554.1097.

39. Typical procedure III: A solution of acetylated spiro-oxathiazoles 13a-d $(150 \mathrm{mg})$ and $\mathrm{NaOMe}(5 \mathrm{mg})$ in $\mathrm{MeOH}(15 \mathrm{~mL})$ was stirred at $\mathrm{rt}$ for $3 \mathrm{~h}$. The reaction was neutralized to $\mathrm{pH}$ 5-6 with Amberlite IR-120 resin $\left(\mathrm{H}^{+}\right.$form $)$and the resin washed with $\mathrm{MeOH}(2 \times 10 \mathrm{~mL})$. The solvent was evaporated under reduced pressure to afford the desired hydroxylated spiro-oxathiazoles 14a-d. Characterization for 14d: $R_{\mathrm{f}}=0.34(\mathrm{EtOAc} / \mathrm{MeOH}, 85: 15) ;[\alpha]_{\mathrm{D}}{ }^{20}+53.2(c 1$, DMSO); $\mathrm{mp}=177-179{ }^{\circ} \mathrm{C} ;{ }^{1} \mathrm{H}$ NMR $\left(300 \mathrm{MHz}, \mathrm{CD}_{3} \mathrm{OD}\right) \delta 3.54(\mathrm{t}, 1 \mathrm{H}, J=9.4 \mathrm{~Hz})$ 3.72-3.98 ( $\mathrm{m}, 5 \mathrm{H}), 7.54-7.60$ ( $\mathrm{m}, 2 \mathrm{H}, \mathrm{H}-\mathrm{ar}), 7.83-7.96$ ( $\mathrm{m}, 4 \mathrm{H}, \mathrm{H}-\mathrm{ar}), 8.06-8.08$
30. Chrysina, E. D.; Kosmopolou, M. N.; Tiraidis, C.; Kardarakis, R.; Bischler, N.; 
(m, 1H, H-ar); ${ }^{13} \mathrm{C}$ NMR (75 MHz, CD $\mathrm{OD}$ ) $\delta 62.0$ (C-6), 70.7, 72.7, 76.2, 77.5 (C2 to $C-5), 124.4,126.8,127.8,128.2,128.9,129.6,129.8,129.9,134.4,136.0$ (aromatics), $157.4(\mathrm{C}=\mathrm{N}) ; \mathrm{MS}(\mathrm{ESI}<0) \mathrm{m} / z=397.9[\mathrm{M}+\mathrm{Cl}]^{-} ; \mathrm{HRMS}(\mathrm{ESI}<0) \mathrm{m} /$ $z=\mathrm{C}_{17} \mathrm{H}_{17} \mathrm{ClNO}_{6} \mathrm{~S}[\mathrm{M}+\mathrm{Cl}]^{-}$Calcd 398.0465. Found 398.0467.
40. Ösz, E.; Somsák, L.; Szilágyi, L.; Kovács, L.; Docsa, T.; Tóth, B.; Gergely, P. Bioorg. Med. Chem. Lett. 1999, 9, 1385.

41. Brochard, L.; Joseph, B.; Viaud, M.-C.; Rollin, P. Synth. Commun. 1994, 24, 1403. 